\title{
Astronomer and Metrologist Fricis Blumbahs (1864-1949)
}

\author{
Jānis Kaminskis \\ Department of Geomatics, \\ Faculty of Civil Engineering, \\ Riga Technical University \\ Āzenes iela 16/20, \\ Rīga LV-1048, Latvia \\ E-mail: Janis.Kaminskis@rtu.lv
}

\section{Jānis Klētnieks}

\author{
Latvian Academy of Sciences \\ Akadēmijas laukums 1, \\ Rīga LV-1050, Latvia \\ E-mail: janis.kletnieks@geostar.lv
}

\begin{abstract}
Fricis Blumbahs (Fritz Blumbach) was one of the first Latvians to acquire higher education in astronomy and he made an outstanding contribution to the culture and science of Latvia during his lifetime. He is known as a research assistant of the prominent Russian scientist Dmitri Mendeleev in the development of metric system of measurement in Russia, in researches in metrology and astronomy, made in cooperation with leading scientists from Western countries of that time. In his old age, Blumbahs became professor of astronomy at the Latvian University and the first Honorary Academician of the Academy of Sciences of Latvian SSR, established in 1946.
\end{abstract}

Keywords: astronomy, Blumbahs, measures of length and weight, Mendeleev, metrology

Fricis Blumbahs was the first child in a family of six children in the Slapari farmstead, Libagi parish, Talsi district on October 11 (23, according to N. S.), 1864, where his father Jānis and his mother Gotliba managed the state land property. He obtained his basic education at his parents' home, but since the age of ten he went to the Talsi Town School. Later he attended the Jelgava Governorate Gymnasium, from which he graduated with good results in 1884 . 
Thereafter he entered the University of Dorpat (Tartu), where he studied at the Faculty of Physics and Mathematics, specializing in physics and astronomy. During his studies, he earned his living at the Meteorological Observatory of the university under Arthur Joachim von Oettingen (1836-1920), a multi-talented professor of natural sciences and of physics, endowed with broad knowledge. Professor Ludwig Struve (1858-1920), grandson of Wilhelm Struve, the founder of the Pulkovo Observatory, was director of the astronomical observatory at that time. Working at the observatory gave Blumbahs good theoretical and practical knowledge in astronomy.

Both professors of Dorpat involved the academically gifted student in serious research. During his last year of studies, the university sent Blumbahs to the Pulkovo Observatory to acquire skills in stellar photography from the astrophysicist B. Haselberg. After this specialized study, Blumbahs photographed Comet Olbers $1887 \mathrm{~V}$ and Sawerthal 1888a at the Observatory of Dorpat, as well as studied the distribution of sound waves in gas explosion under the guidance of professor Oettingen. On the basis of this research, Blumbahs developed and in autumn 1889 defended the degree of Candidate of Sciences in Physics (Rabinowitz, 1965).

After graduating from the university, Blumbahs started work at the Pulkovo Observatory as a freelance astronomer and was sent abroad to deepen his knowledge of astrophysics at observatories in Germany, France and England. Meanwhile, members of the board of the Pulkovo Observatory were replaced. Due to the Russification policy pursued in Russia, Hermann Struve, director of the observatory, was dismissed from his post and Fyodor Bredikhin (1831-1904), astronomer and comet researcher at the Moscow University, was appointed instead of him. The new director made changes in the staff of the observatory. Astronomers with German surnames, including Blumbahs, were dismissed from their positions.

Regarding his dismissal from Pulkovo, Blumbahs wrote in his curriculum vitae: "After the change of directors of Pulkovo in 1890, I was dismissed from Pulkovo together with Vanahs (Vanags), a former fellow-student of the Dorpat University, because Pulkovo Observatory is rather Germanized, although I have never in my life pretended to be German and have always held the belief that scientists are one nation or community" (Blumbahs, 1984, p. 44).

However, his knowledge in the area of precise physical measurements, acquired earlier at the Dorpat University, Pulkovo Observatory and abroad, opened the door 
for Blumbahs to further his research activities. He was invited by Nikolai Yegorov (1849-1919), professor of physics at the Saint Petersburg Academy of Military Medicine, to work as an assistant in the laboratory of physics. The laboratory led by Professor Yegorov also worked in the branch of metrology and cooperated with the famous chemist Dmitri Mendeleev, who had managed the main Russian Bureau of Weights and Measures, also known as the Depot, since 1890. The cooperation between the two scientists caused essential changes in Blumbahs's subsequent life. Mendeleev paid attention to Blumbahs's wide range of knowledge in physics and mathematics, and appreciated the precision of the physical measurements obtained in the laboratory. Due to these qualities which are essential in scientific activities, towards the end of 1893, Mendeleev engaged Blumbahs as a mechanic in the newly established Main Bureau of Weights and Measures.

The main task of the Bureau of Weights and Measures was to ensure and control the usage of measures of length, weight and other physical measurements. Until the mid-nineteenth century, different measurement units were in use in the governorates of Russia, which impeded the development of trade and other branches of economy. Only in the middle of the $19^{\text {th }}$ century, the state administration focused on the issue of standardization of measures to ensure a unified measuring system. A special commission of weights and measures was established. It was led by Adolph Theodor Kupffer (1799-1865), who was born in Mitau (Jelgava) and was a member of the St. Petersburg Academy of Sciences. This commission developed the basic principles for a unified measurement system and applied it to the measures for general use in Western European countries. The main Depot of Standard Weights and Measures was founded in St. Petersburg and in 1835 a law determining the basic units of Russian measurement system and their correlation was passed (Polnoe sobraniie..., 1835, p. 1010). Girgensohn, a mechanic of the Academy of Sciences, made prototypes of measures of length - sazhen $(2.1336 \mathrm{~m})$ and arshin $(71.12 \mathrm{~cm})$, as well as of the measure of weight (Travaux..., 1841). The prototypes of measures were deposited at the Depot of Weights and Measures, which was responsible for providing a duplicate for each governorate. The unified measurement system in Russia was adopted, as prescribed by the law, on January 1, 1845 (Polnoe sobraniie..., 1845).

The development of the Russian system of weights and measures was based mainly on broad researches in metrology performed by Magnus Georg Paucker, professor of mathematics at the Jelgava Academic Gymnasium (Kurzemes zinātnieks..., 2012, p. 46). However, in the course of time, as researches in the area of metrology 
and branches of physics developed, stricter requirements were imposed on the manufacturing of standards of measurement. After French scientists abandoned their original idea to connect the measure of length metre with the length of arc of the quarter of the meridian of the Earth due to technical reasons to achieve the needed accuracy, the decimal system of measurement was established in Western Europe. Russia also joined the international convention of weights and measures in 1875. The International Bureau of Weights and Measures-Bureau International des poids et mésures - was established in Paris. This bureau defined the form and material of prototypes. In 1883-1887, prototype samples were manufactured of alloy of platinum and iridium. ${ }^{1}$ Russia received two prototypes of metre-No. 11 and No. 28, as well as a prototype of the kilogram.

As Mendeleev took over the management of the Depot of Weights and Measures in 1890, the manufacturing of new Russian prototypes of measures and comparison of them with the internationally adopted system of measurements was the most important task. The former Depot of Weights and Measures was reorganized as the Main Bureau of Weights and Measures. Blumbahs worked in this Bureau of Weights and Measures for almost thirty years (1893-1921) and became one of Mendeleev's closest colleagues. Already in the first year, he was sent to England on behalf of professor Mendeleev to supervise the manufacturing and verification and check the true quantity of the ordered prototypes of measures of length and weight. According to Mendeleev's instructions, the new prototypes of measures had to ensure an at least 20 times higher precision than previously manufactured prototypes, while taking into account the interrelation between the English yard and metre: 1 yard $=0.914400$ metres.

The accuracy with which all the tasks were carried out and the high quality of the manufactured standards of measurements ensured Blumbahs Mendeleev's recognition and favour. In the winter of 1895, the new prototypes of measures were transported to St. Petersburg, where their final research and comparison with prototypes of earlier measures was continued for several years. In 1899, a new law on measures and weights was passed in Russia, according to which the units of measurements were made more exact and compared with the measures of the decimal and the British system (Blumbah, 1924).

Simultaneously with research into the quality of prototypes of measures, Blumbahs took part in the inspections of control of measures in various regions

\footnotetext{
Prototypes are manufactured of an alloy of $90 \%$ platinum and $10 \%$ iridium with specific weight 21.5 . The measure of length metre has the shape of letter $\mathrm{X}$, but the unit of weight kilogram has the shape of a cylinder.
} 
of Russia. The first inspection trip was to Eastern Siberia and it joined the expedition organized by the Russian Astronomical Society for the observation of the total solar eclipse on July 28 (according to O. S.), 1896 in Yakutia, where the Chekurskoye village at the Lena River was within the path of the total eclipse. During the total eclipse, Blumbahs managed to take high-quality photographs of the corona of the Sun with a long-focus camera for photography of the solar corona. The photographs he obtained had a great importance for the research of the corona of the Sun. The results of the expedition of the solar eclipse were published in 1912 (Trudy..., 1896). As the responsible official of the Main Bureau of Weights and Measures, Blumbahs also had the task to carry out the control of weights and measures in this remote region of the country ('Dannye...', 1896).

In April 1900, Blumbahs had the task to carry out an inspection in the Baltic countries to obtain information about the situation of measures in Riga, Liepāja, Ventspils and Reval. For the inspection, a precise sample of arshin with markings of vershoks $(4.445 \mathrm{~cm})$ and inches $(2.54 \mathrm{~cm})$, as well as the standard measure of pound $(453.59 \mathrm{~g})$ was used for the control of weights. Materials collected in the inspection demonstrated that in many cities, with the exception of Riga, there was a lack of standard measures and weights necessary for the comparison of trade measures. Also, there was a lack of people qualified to inspect measures. However, the situation in general was better than in other regions of Russia. According to Blumbahs's recommendation, Riga was selected as the city in which the bureau for the supervision of measures, also known as the Bureau of Measures, was established in 1902 (Zemzaris, 1984).

In these years, Mendeleev entrusted Blumbahs with a task to create a laboratory for accurate time measurement, which would establish the definition, storage and transmission of the time standard - the second. For the needs of the laboratory, astronomical clocks were purchased from the Riefler and a transit instrument from Bamberg, and a tower was built for astronomical observations for the determination of clock corrections. The time standard laboratory synchronized the clocks of the Winter Palace and of the Ministry of Finances to the signals of the second at the start of the activities, but afterwards it distributed the standard of second to telegraph, railway, post and other institutions, ensuring a unified system of accurate time throughout the country.

At the end of 1906, Blumbahs was sent on an inspection of weights and measures to the region of Turkestan. This time the inspection trip was also combined with the observation of a total solar eclipse. Due to adverse atmospheric 
conditions, he could not observe the eclipse; however, he succeeded in carrying out the inspection of measures in many settlements of Turkestan (Blumbah \& Stankevich, 1908).

On January 20, 1907, Dmitri Mendeleev, head of the Main Bureau of Weights and Measures, passed away. ${ }^{2}$ Blumbah's scientific ideas were formed in cooperation with this eminent scientist. Mendeleev's aspirations to reach the highest precision or accuracy in scientific research became the leading motive of Blumbahs's subsequent life and accomplishments. Professor Yegorov, who had been Blumbahs's superior at the Military Academy of Medicine, was appointed the head of the Main Bureau of Weights and Measures. Blumbahs continued to manage the laboratory of accurate time standards, but the new head of the bureau did not support the research started during Mendeleev's time. Yegorov's management style manifested itself more in administration than in research.

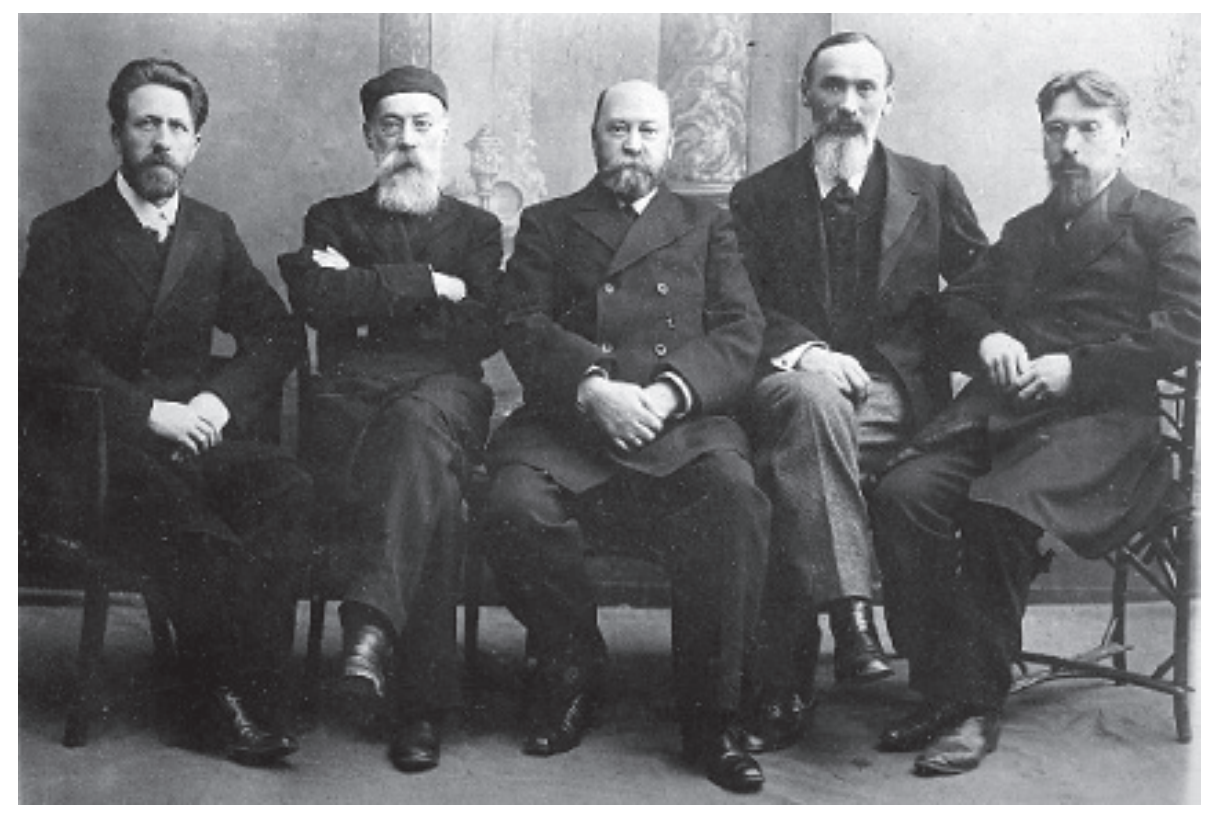

Figure 1. The metrologists of the Russian Bureau of Weights and Measures at the beginning of the $20^{\text {th }}$ century. From the left: V. Miller, N. Yegorov, F. Zavadski, F. Blumbahs and A. Dobrokhotov.

$2 \quad$ Blumbahs memorialized Mendeleev in many photographs. One of the portraits of Mendeleev taken by Blumbahs is depicted on the postage stamp of 15 roubles issued in Russia in 2009. 
As a result, research activities were reduced and next to his direct duties in the laboratory of accurate time, Blumbahs focused on pedagogic work and taught physics at St. Petersburg Higher Polytechnic Courses for Women (LVVA, 1945). In 1914, he took part in yet another expedition organized by the Russian Astronomical Society for the observation of the total solar eclipse. However, due to adverse atmospheric conditions, he failed to obtain photographs of the Sun.

After the 1917 revolution, on September 14, 1918, the government of Soviet Russia issued a decree on transition to the metric system of measurements. The Main Bureau of Weights and Measures had to reorganize its activities in the complicated circumstances of the Civil War in order to accomplish this reform in the immediate future. In summer 1919, Professor Yegorov passed away and for a while the duties of head of the Main Bureau of Weights and Measured were entrusted to Fricis Blumbahs. In autumn 1921, the Supreme Soviet of the National Economy selected Blumbahs as one of the scientists and technicians to be sent abroad to solve issues concerning the astronomical instruments that Russia had ordered in the pre-war years. At the same time, the regular conference of the International Committee of Weights and Measures was summoned in Paris, where Blumbahs was also approved as a representative of the Soviet Russia.

This was the start of a new stage of creative activities in Blumbahs's life. After the Paris conference, Blumbahs went to Geneva to supervise the manufacturing of the comparator of the size of 4 metres ordered in the pre-war period for the purpose of controlling measures of length. In the manufacturing of the complicated equipment, Blumbahs placed high demands on precision, and it resulted in the most precise comparator of measures of length of that time. In 1928, after the final check, the new measurement equipment was transported to Leningrad and installed in the Main Bureau of Weights and Measures, which was later reorganized into the Metrological Scientific Research Institute. ${ }^{3}$

In Geneva, Blumbahs took part in the quality assessment of the assembling of optical and mechanical parts of a parabolic mirror telescope, manufactured in the local observatory. This proved useful for his subsequent activities, when he managed the manufacturing of optical telescopes ordered in England. In 1913, the Pulkovo Observatory had entered into contract with the famous British optical instrument firm Howard Grubb concerning the manufacturing of three large instruments-a 40-inch mirror telescope-reflector, a 32-inch lens telescope-refractor, and a spectrograph. During the war, part of the order had already been completed. On

The present-day D. I. Mendeleev Institute for Metrology (Metrologicheskii institut Gosstandarta Rossii VNIIM im. D. I. Mendeleeva). 
behalf of the Mission of Foreign Trade of Soviet Russia, Blumbahs succeeded in having the contract of manufacturing of the spectrograph and reflector reinstated (Rabinovičs, 1963). The manufacturing of the large refractor's objective was not started and the reinstating of the contact was temporarily postponed. Blumbahs tried to make sure that the British manufacturers of optical glass casted sufficiently high-grade glass discs without internal stresses, which would be useful for the manufacturing of the achromatic objective 32 inches in diameter. ${ }^{4}$ However, these efforts failed to bring the desired success.

Grinding of the mirror of 40-inch reflector in the Howard Grubb workshop was more successful, but separate units of the telescope assembly were defective. Only Blumbahs's energetic interference helped to eliminate the constructive imperfections of the assembly of the mirror. Unfortunately, the reflecting telescope manufactured in the firm was not controlled under real conditions of photographing stars as Blumbahs had demanded. The testing commission appointed by the Soviet government accepted the instrument without this final check. The new 40-inch mirror telescope was transported to Russia and was installed in the southern branch of the Pulkovo Observatory in Simeiz, Crimea in 1926. As Blumbahs had foreseen, the mirrors of the telescope had to be corrected to adjust them for the observation of stars. ${ }^{5}$

After the telescope was shipped, Blumbahs stayed in England, because the Mission of Foreign Trade commissioned him to establish a laboratory in London to research the quality of gasoline and lubricating oils manufactured in the Soviet Union to be marketed in the world markets. In 1928-1934, the laboratory proved the high quality of petroleum products of Baku, which exceeded that of analogous American products. Working in the laboratory saturated with vapors of gasoline damaged the health of the 70-year-old scientist and he left London on the recommendation of physicians. Blumbahs moved to Sidmouth in South West England and found a job in the local Norman Lockyer Observatory. On August 7-9, 1937, he took photographs of Comet Finsler 1937f with the observatory's 5.5-inch Zeiss astrograph. ${ }^{6}$ The Royal Astronomical Society of England recognized these as prominent observations and set them as a model in the collection of the astronomical photographs (LVVA, 1945).

At Greenwich Observatory, a refracting telescope with a 26-inch objective was is use at that time. The largest refracting telescope, with a diameter of 40 inches, was manufactured in the USA and is installed at Yerkes Observatory (1897).

5 The mirror telescope of Simeiz was used for photographing stars until the Second World War. During the war it was dismantled by Germans and irretrievably damaged during transportation.

6 Comet $1937 \mathrm{f}$ was discovered by Paul Finsler, astronomer at Zurich Astronomical Observatory on July 4, 1937. The comet was an object of $7^{\mathrm{m}}$ without the tail at the moment of the discovery. 


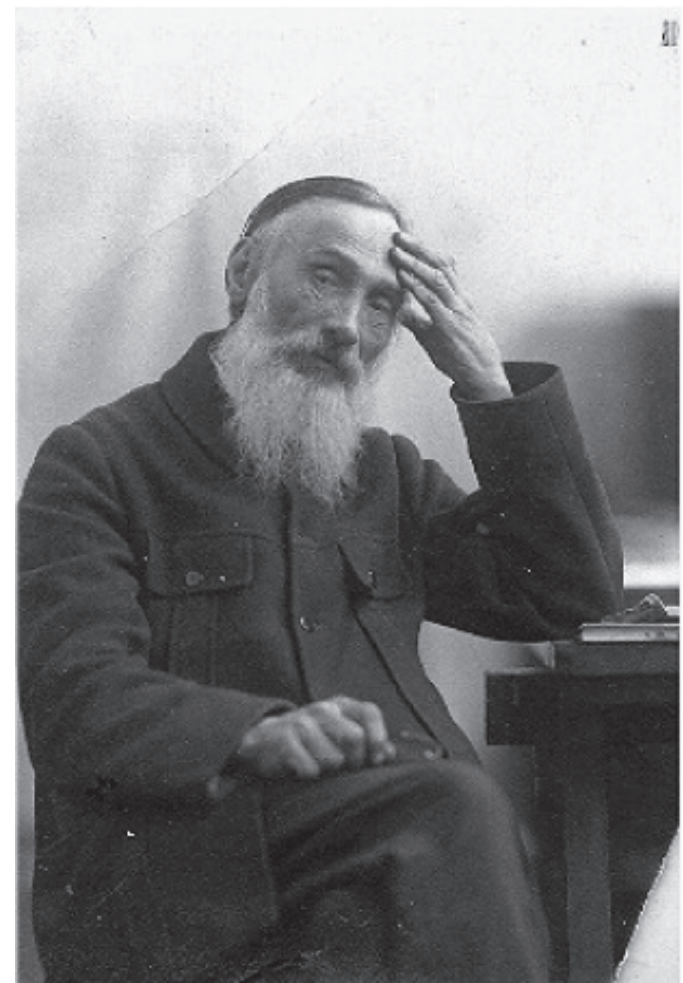

Figure 2. Fricis Blumbahs.

Shortly before the Second World War, on 20 August 1939, Blumbahs returned to his homeland upon the invitation of the Latvian University and was elected a private associate professor of the Astronomical Observatory (Historical..., 1939). His main duty was to supervise and record the pace of astronomical clocks. However, his scientific talent and creativity became apparent also in these duties. Blumbahs improved the construction of the device for reading chronograms of the signal of the second, which was used in the observatory for processing observations. In autumn 1940, the Latvian State University established by Soviets approved Blumbahs as professor in the Chair of Astronomy, but in the subsequent period of German occupation his former status was reinstated.

After the Soviet rule was restored in autumn 1944, the Faculty of Physics and Mathematics of the Latvian State University re-elected Blumbahs as professor and head of the Chair of Astronomy. The title of honorary scientist was awarded to the elderly professor in 1945. Blumbahs participated in the establishment of the Academy of Sciences of the Latvian SSR and was elected honorary academician in 1946. Next to his work at the Latvian State University, Blumbahs also worked as head of the Astronomy Section of the Academy of Sciences. A new generation of astronomers grew up under the guidance of Professor Fricis Blumbahs.

Though born in Kurzeme, Blumbahs had a broad understanding of the great world of science and travelled widely during his lifetime. The sparkling stars from the sky of his childhood followed him always and everywhere. Fricis Blumbahs 
passed away on 10 June 1949 at the age of 84 in Riga and is buried on the hill of scientists' tombs in the Forest Cemetery (Rabinovičs, 1964). There is a tombstone made by the sculptor Uldis Stergis symbolizing the world of a man positioned between earth and heaven.

\section{References}

Blumbah, F. (1924), Tablici dlia perevoda Russkikh mer v metricheskoe i obratno. RSFSR, Naucno-tekhnicheskii otdel VSNH, A. Serija 1, rabochaia biblioteka 13-2, Goje izdanije, Leningrad: Tekhnicheskoe izdatelstvo.

Blumbahs, F. (1984), 'Curriculum vitae,' Zvaigžnotā Debess, Rudens, pp. 44-46.

Blumbah, F. I. \& Stankevich, B. V. (1908), Turkestanskaia ekspeditsiia dlia nabliudeniia polnogo solnechnogo zatmeniia 1 (14) ianvaria 1907 goda, sostoiavshaia pod pokrovitel'stvam Imperatorskogo Russkogo geograficheskogo obshchestva, St. Petersburg: tip. M.M. Stasiulevicha.

'Dannye...' (1896), 'Dannye o vyverke mer i vesov v Sibirii: iz otcheta predstavlennovo poveritelam Glavnoi Palati F. I. Blumbahom,' Vremennik glavnoi palaty mer i vesov, St. Petersburg, vol. 3, pp. 124-132.

Kurzemes zinātnieks... (2012), Kurzemes zinātnieks profesors Dr. Magnuss Georgs Paukers 1787-1855: Rakstu kräjums, Rīga: RTU izdevniecỉba, pp. 46-50.

LVVA (1945), Personal file of the Latvian University professor F. Blumbach, 1939-1949, LVVA F 7427, inv 13, f 228, Latvian State Historical Archives, Riga.

Polnoe sobraniie... (1835), Polnoe sobraniie zakonov Rossiiskoi imperii 2, Saint Petersburg, vol. 10 , no. 8459 .

— (1845), Polnoe sobraniie zakonov Rossiiskoi imperii 3, Saint Petersburg, vol. 17, no. 15018 .

Rabinovičs, I. (1963), 'Par Friča Blumbaha piedalī̌̌anos lielā Simeizas teleskopa izgatavošanā,' Astronomiskais Kalendārs 1964. Rīga: Latvijas PSR Zinātṇu Akadēmijas izdevniecība, pp. 103-113.

— (1964), 'Frici Blumbahu pieminot,' Zvaigžn,notā debess, Rudens, pp. 42-47.

Rabinowitz, I. M. (1965), Na straze tochnosti. Stranici iz zhizni i deiatelnosti F. I. Blumbahai, Riga: Latviiskoe Gosudarstvennoe izdatelstvo.

Travaux... (1841), Travaux de la Commission pour fixer les mesures et les poids de l'Empire de Russie, Saint-Pétersbourg: Imprimerie de l'Expedition de la Confection des Papiers de la Couronne. 
Trudy... (1912), Trudy ekspedicii, snarazhennykh Russkim astronomicheskim obshchestvom dlia nabliudeniia polnogo solnechnogo zatmneniia 28 iulia (9 avgusta) 1896 goda, St. Petersburg: Tipografija Morskovo ministerstva.

Zemzaris, J. (1984), 'F. Blumbaha sadarbība ar D. Mendel̦ejevu praktiskajā metrolog̣ijā,' Zvaigžnotāa Debess, Rudens, pp. 48-53.

Jānis Kaminskis earned his first degrees in theoretical physics and astronomy from the University of Latvia (1990) and his Dr.sc.ing. in geodesy from the Riga Technical University (2010). During his research he has worked for a few years at the Finnish Geodetic Institute, also at the National Survey of Denmark, and Copenhagen University. Currently he is visiting researcher at the ETH Zurich in Switzerland.

Jānis Klētnieks graduated from the Latvian University of Agriculture (land survey) in 1953 and completed doctorate studies at the Lomonosov Moscow State University (astronomy) in 1961. He is docent emeritus of geodesy at the Riga Technical University and doctor honoris causa of the Latvian Academy of Sciences. He conducts research in astronomy, geodesy and the history of sciences. 